\title{
Biochemical Toxicity Induced By Tramadol Administration In Male Rats
}

\author{
Inass I. El-Gaafarawi \\ The National Center for Social and Criminological Research, \\ Zamalek P.O., P.C.11561, Cairo, Egypt.
}

\begin{abstract}
Introduction: Tramadol is a centrally acting analgesic used for treatment of moderate to severe pain. There has been some controversy regarding the dependence lability of long- term use of this medication. The present work was conducted to assess the biochemical toxicity profiles of tramadol during therapeutic use. Liver and kidney functions, sex hormones activity and some metabolic parameters were studied in male rats.

Methods: Rats were divided into three groups. Group one received vehicle (saline), group two and three received oral doses of tramadol equal to $40 \mathrm{mg}$ and $80 \mathrm{mg} / \mathrm{kg}$ body weight / day respectively for a month followed by 10 days recovery period. Biochemical measurements were carried out every 10 days.

Results: There was significant increase in the levels of serum aminotransferases (ALT,AST), lactate dehydrogenase (LDH), urea nitrogen (BUN),creatinine and lipid peroxide ( MDA) in both tramadol groups. In contrast, serum glucose, total cholesterol and triglycerides were significantly reduced. Tramadol significantly reduced serum luteinizing hormone (LH), follicle stimulating hormone (FSH), testosterone and cortisol, but elevated prolactin (PRL) and estradiol $\left(\mathrm{E}_{2}\right)$ in male rats specially at 20 and 30 days of treatment. After 10 days recovery, 80 mg tramadol group remained significantly different compared to control one.

Conclusion:The present finding pointed out the risk of increased lipid peroxidatin, hepatic and renal damage and sexual dysfunction. Tramadol toxic effects should be kept in mind during long term therapy specially in large doses.
\end{abstract}

\section{Introduction}

Tramadol (Tramal ${ }^{\mathrm{TM}}$ ) is a synthetic, centrally acting analgesic used parent-erally and orally for the treatment of moderate to severe pain. The mechanism of tramadol analgesic action is complex. Most reports suggest that the analgesic activity and other clinical effects of tramadol are a result of opioid and non-opioid mechanisms. Tramadol binds to the $\mu$-opioid receptor, although much more weakly than morphine. It also inhibits the neuronal reuptake of norepinephrine and serotonin as do the antidepressant drugs such as amitriptyline and desimpramine (Raffa et al., 1992; Raffa, 1996; Dayer et al.,1997; Grond and Sablotzki, 2004; Gillman, 2005).

Tramadol has high oral bioavailability in the range of 70-80\%. Peak blood levels are reached in about 2 hours after an oral dose. The drug is converted in the liver to at least one active metabolite (Odesmethyl-tramadol: ML), which itself is 2 to 4 times more potent than tramadol $(\mathrm{Wu}$ et al., 2001; Tao et al., 2002; JanssenOrtho Inc., 2005). Its opioid activity is greater than the parent compound and could contribute to this component (Lewis and Han, 1997; Grond and Sablotzki, 2004). The parent drug and metabolites are mainly excreted via kidneys (Matthiessen et al., 1998; Janssen- Ortho Inc., 2005).

Tramadol has a dose- dependent analgesic efficacy that lies between that of codeine and morphine, with a parenteral potency comparable to that of pethidine, i.e. about $10-20 \%$ of the standard morphine 
(Wilder- Smith et al., 1999; Pang et al., 2003). The efficacy of tramadol is not associated with the usual serious opioid side effects. Nausea is perhaps the most common side effect and may occur with the same frequency as codeine therapy. Dizziness, constipation and headache have been reported with chronic use (Cossman and Cohnen, 1995). Respiratory depression has not been observed, but large doses of tramadol may increase the respiratory effects of other drugs (Houmes et al., 1992; Tarkkila et al., 1998). Seizures have been reported in patients receiving recommended doses but are more likely associated with abuse of this medication (Jick et al., 1998; Gasse et al., 2000). When seizures do occur, they are commonly of short duration and are easily treatable (Spiller et al., 1997; Tobias, 1997; Gardner et al., 2000).

Unlike nonsteroidal anti-inflammatory drugs, tramadol has no serious adverse gastrointestinal effects such as gut, platelet or renal effects of that drug class (Gibson, 1996; Tolman, 1998).

The incidence of abuse of tramadol is low in all post- marketing surveys; the Food and Drug Administration reported a rate of abuse in the range of 1 in 100,000 patient exposures (FDA, 1998). Rare cases of withdrawal reactions after abrupt discontinuation of tramadol have been reported (Cossman and Cohnen, 1995). But Poison Control data (2002 AAPCC Annual Report) indicated that there were 2,400 exposures of tramadol reported to control centers, of those, 108 resulted in a major medical outcome and 8 resulted in death.

Long- term administration of tramadol for management of pain, as well as its use as an acceptable alternative in persons with drug- seeking behavior is controversial (Drugs and Therapy Bulletin, 2002). Also, long- term effects of tramadol at cellular level, are not clearly understood (Atici, 2005).

So, the present work was conducted to assess the biochemical toxicity profiles of this medication (tramadol $\mathrm{HCl}$ ) during one month treatment and 10 days recovery period. Liver and kidney functions, some metabolic parameters and sex hormones activity were studied in male rats (Rattus norvegicus).

\section{Materials and Methods}

\section{Drug:}

Tramal (Tramadol $\mathrm{HCl}$ ), $50 \mathrm{mg}$ capsules, was obtained from Mina- Pharm, Egypt. Its chemical name is $( \pm)$ cis-2[(dimethylamino)methyl]-1-(3-m ethoxyphenyl) cyclohexanol hydrochloride.

\section{Experimental Protocol:}

110 male rats (Rattus norvegicus) weighing $150 \pm 5 \mathrm{~g}$ were used in the present study. All rats were housed in a quite nonstressful environment for one week before study. They were given normal rat chows ad libitum during the experimental period. They were allowed free access to water. Animals were divided into three groups. The first one was comprised 30 rats, served as control and administered oral doses of saline solution for a month. The second and third groups, each comprised 40 rats, were administered oral doses of tramadol $\mathrm{HCl}$ suspended in saline solution equal to $40 \mathrm{mg}$ and $80 \mathrm{mg} / \mathrm{Kg} \mathrm{b}$. wt. /day for a month respectively. Ten rats from each tramadol group were left ten days more without any additional treatment as a recovery period after one month exposure.

Doses calculated for animals using Paget and Barnes (1964) species intercoversion table of dosage.

Control and treated rats were sacrificed at the end of 10,20,30, and 40 days respectively. Blood was collected in dry centrifuge tubes. Sera were separated and kept at $-20^{\circ} \mathrm{C}$ until analysis.

\section{Biochemical Analyses:}

-Alanine aminotrasferase (ALT) and Aspartate aminotransferase (AST) activities were measured using the method of Thomas (1998).

-Lactate dehydrogenase (LDH) was measured by the Scandinavian assay (1974).

-Creatinine (Creat.) was determined using the method of Fossati et al.(1983). 
-Urea (BUN) was measured according to Orsonneau et al.(1992).

-Glucose (Glu.) was determined by Trinder (1969) enzymatic method.

-Total Cholesterol (TCh.) was determined according to the method of Flegg (1973).

-Triglycerides (TG.) were measured by the method of Fossati and Prencipe (1982).

-Malondialdhyde (MDA) was measured by the method of Albro et al.(1986). The amount of lipid peroxides were calculated as thio- barbituric acid reactive products of lipid peroxidation and reported as nmol of malondialdhyde per $\mathrm{ml}$ of serum.

-Luteinizing hormone (LH), follicle stimulating hormone $(\mathrm{FSH})$, prolactin (PRL), testosterone (Tes.), estradiol $\left(\mathrm{E}_{2}\right)$ and cortisol (Cor.) were determined using enzyme linked immunosorbant assay (ELISA) kits according to manufacture structure.

\section{Statistical Analysis:}

All data were expressed as means \pm standard errors. Data of different groups were compared using Student's t- test. Differences at $p<0.05$ were considered significant.

\section{Results}

Data in Table (1) showed that administration of $40 \mathrm{mg}$ tramadol $/ \mathrm{Kg} \mathrm{b}$. wt./day significantly increased serum ALT, AST and LDH levels at first, second and third ten days of treatment compared to control group $(\mathrm{p}<0.05, \mathrm{p}<0.01$ and $\mathrm{p}<0.01$ respectively). Also, BUN and creatinine were significantly elevated at third ten days of treatment $(\mathrm{p}<0.05)$ while, lipid peroxides (MDA) increased gradually and significantly from the first ten days treatment till one month $(\mathrm{p}<0.05, \mathrm{p}<0.01$ and $p<0.01$ respectively). Glucose, total cholesterol and triglycerides were reduced significantly at 20 and 30 days of treatment $(\mathrm{p}<0.05$ and $\mathrm{p}<0.01)$. On the other hand, after ten days recovery period ALT, AST, $\mathrm{LDH}, \mathrm{BUN}$ and creatinine returned to their levels, yet did not reach the corresponding control group, except of glucose, cholesterol, triglyc-erides and MDA which were significantly different from control group $(\mathrm{p}<0.05)$.

Results presented in Table (2) indicated that administration of $80 \mathrm{mg}$ tramadol $/ \mathrm{Kg} \mathrm{b}$. wt./day was significantly induced the elevation of ALT, AST, LDH and MDA at 10, 20 and 30 days of treatment $(\mathrm{p}<0.01)$. BUN and creatinine also increased at 20 and 30 days of treatment $(\mathrm{p}<0.05$ and $\mathrm{p}<0.01$ respectively). But glucose, total cholesterol and triglycerides reduced significantly at 20 and 30 days of treatment $(\mathrm{p}<0.01)$ comp-ared to control. The ten days recovery group remained significantly different compared to control group.

Table (3) showed that $40 \mathrm{mg}$ tramadol $/ \mathrm{Kg}$ b. wt. statistically elevated serum $\mathrm{E}_{2}$ and PRL secretions with a decrease in testosterone levels at 20 days of treatment, whereas at 30 days $\mathrm{LH}, \mathrm{FSH}$, testosterone and cortisol were significantly reduced accompaning with significant increase of $E_{2}$ and PRL secretions. After ten days recovery, the measuring param-eters reached their normal levels except testosterone and $E_{2}(p<0.05)$ which still recorded significant increase compared to control group.

Data in Table (4) revealed that after 20 and 30 days of treatment with $80 \mathrm{mg}$ tramadol $/ \mathrm{Kg} \mathrm{b}$. wt., there were significant increase in $\mathrm{E}_{2}$ and PRL $(\mathrm{p}<0.01)$ compared to control. Also, there were higher significant reduction in testosterone and cortisol ( $\mathrm{p}<0.01)$ accompanied by gradual reduction in LH and FSH levels observed at 20 and 30 days $(\mathrm{p}<0.05$ and $\mathrm{p}<0.01$ respectively). The recovery group was noted to be significantly elevated over corresponding control group. 
Table (1): Effect of Tramadol (40 mg/kg/day) Administration on Biochemical Profile of Male Rats.

\begin{tabular}{|c|c|c|c|c|c|}
\hline \multirow[b]{2}{*}{ Parameters } & \multirow{2}{*}{$\begin{array}{l}\text { Control } \\
\mathrm{X}_{ \pm} \text {S.E. }\end{array}$} & \multicolumn{3}{|c|}{ Treatment (1 month) } & \multirow{2}{*}{$\begin{array}{c}\text { Recovery } \\
10 \text { days } \\
\text { X+S.E. }\end{array}$} \\
\hline & & $\begin{array}{l}10 \text { days } \\
X_{ \pm} \text {S.E. }\end{array}$ & $\begin{array}{l}20 \text { days } \\
X_{ \pm} \text {S.E. }\end{array}$ & $\begin{array}{l}30 \text { days } \\
X_{ \pm} \text {S.E. }\end{array}$ & \\
\hline ALT(U/L) & $35.2 \pm 2.0$ & $43.6 \pm 1.1 *$ & $48.2 \pm 1.0 * *$ & $55.3 \pm 0.9 * *$ & $40.3 \pm 1.1$ \\
\hline $\mathrm{AST}(\mathrm{U} / \mathrm{L})$ & $126.4 \pm 2.3$ & $143.0 \pm 1.4 *$ & $188.0 \pm 1.2 * *$ & $203.0 \pm 2.6 * *$ & $130.0 \pm 1.2$ \\
\hline $\mathrm{LDH}(\mathrm{U} / \mathrm{L})$ & $556.0 \pm 3.2$ & $590.0 \pm 2.4 *$ & $660.0 \pm 2.2 * *$ & $806.0 \pm 3.0^{* * *}$ & $562.0 \pm 1.0$ \\
\hline $\mathrm{BUN}(\mathrm{mg} / \mathrm{dl})$ & $24.2 \pm 1.9$ & $25.8 \pm 1.0$ & $28.3 \pm 1.1$ & $38.0 \pm 1.3 *$ & $30.4 \pm 1.2$ \\
\hline Creat.(mg/dl) & $0.4 \pm 0.12$ & $0.41 \pm 0.1$ & $0.42 \pm 0.11$ & $0.56 \pm 0.1 *$ & $0.43 \underline{+} 0.11$ \\
\hline Glu.(mg/dl) & $205+2.2$ & $200 \pm 2.0$ & $189 \pm 1.4 *$ & $170 \pm 1.9^{* *}$ & $186 \pm 1.5^{*}$ \\
\hline TCh. (mg/dl) & $83.5 \pm 2.0$ & $82.0 \pm 1.3$ & $70.0 \pm 1.0 *$ & $62.0 \pm 1.0 * *$ & $75.3 \pm 1.3 *$ \\
\hline TG. $(\mathrm{mg} / \mathrm{dl})$ & $92.3 \pm 2.2$ & $88.3 \pm 1.2$ & $80.0 \pm 1.0^{*}$ & $75.0 \pm 1.2 * *$ & $81.5 \pm 1.6^{*}$ \\
\hline $\mathrm{MDA}(\mathrm{nmol} / \mathrm{ml})$ & $6.3 \pm 1.0$ & $11.9 \pm 0.9^{*}$ & $18.2 \pm 0.8 * *$ & $26.0 \pm 0.66^{* * *}$ & $9.2 \pm 0.32 *$ \\
\hline
\end{tabular}

$*=$ Significant $(\mathrm{p}<0.05)$

$* *=$ Highly significant $(\mathrm{p}<0.01)$

Control $=$ The average of the results of control groups were used in the statistical analysis as there is no significant difference between them.

Table (2): Effect of Tramadol $(80 \mathrm{mg} / \mathrm{kg} / \mathrm{day})$ Administration on Biochemical Profile of Male Rats.

\begin{tabular}{|c|c|c|c|c|c|}
\hline Conditions & Control & \multicolumn{3}{|c|}{ Treatment(1 month) } & Recovery \\
\hline Parameters & X+S.E. & $\begin{array}{l}10 \text { days } \\
\text { X } \pm \text { S.E. }\end{array}$ & $\begin{array}{l}20 \text { days } \\
\text { X+S.E. }\end{array}$ & $\begin{array}{l}30 \text { days } \\
\text { X } \pm \text { S.E. }\end{array}$ & $\begin{array}{l}10 \text { days } \\
\text { X+S.E. }\end{array}$ \\
\hline$\overline{A L T}(\mathrm{U} / \mathrm{L})$ & $35.2 \pm 2.2$ & $53.6 \pm 1.4 *$ & $64.0+1.6 * *$ & $69.0+1.3 * *$ & $49.9+1.3 *$ \\
\hline $\mathrm{AST}(\mathrm{U} / \mathrm{L})$ & $126 . \overline{4+2.3}$ & $156.0+2.0 *$ & $196.0+1.5 * *$ & $220.0+2.3 * *$ & $153.0+2.0 *$ \\
\hline $\mathrm{LDH}(\mathrm{U} / \mathrm{L})$ & $556.0 \pm 3.2$ & $686.0 \pm 2.4 * *$ & $803.0 \pm 3.0 * *$ & $930.0 \pm 2.9 * *$ & $708.0 \pm 2.0 *$ \\
\hline $\mathrm{BUN}(\mathrm{mg} / \mathrm{dl})$ & $24.2 \pm 1.9$ & $27.0 \pm 1.0$ & $39.5 \pm 1.0 *$ & $50.6 \pm 1.3 * *$ & $32.3 \pm 0.9 *$ \\
\hline Creat.(mg/dl) & $0.4 \pm 0.10$ & $0.42 \pm 0.1$ & $0.58 \pm 0.1 *$ & $0.65 \pm 0.11 * *$ & $0.50 \pm 0.1 *$ \\
\hline Glu.(mg/dl) & $205 \pm 2.2$ & $195 \pm 1.9$ & $176 \pm 2.0 * *$ & $150 \pm 1.1 * *$ & $183 \pm 1.3^{*}$ \\
\hline TCh. (mg/dl) & $83.5 \pm 2.0$ & $80.3 \pm 1.3$ & $70.5 \pm 1.0 * *$ & $60.0 \pm 1.0 * *$ & $68.3 \pm 1.2 *$ \\
\hline TG. $(\mathrm{mg} / \mathrm{dl})$ & $92.3+2.2$ & $86.0 \pm 2.0$ & $73.6+1.3 * *$ & $62.0 \pm 1.0 * *$ & $80.5 \pm 1.2 *$ \\
\hline MDA(nmol/ml) & $6.3 \pm 1.0$ & $16.3 \pm 1.1 * *$ & $20.5 \pm 1.2 * *$ & $35.0+1.1 * *$ & $19.6 \pm 1.0 *$ \\
\hline
\end{tabular}

$*=$ Significant $(\mathrm{p}<0.05) \quad * *=$ Highly significant $(\mathrm{p}<0.01)$

Control $=$ The average of the results of control groups were used in the statistical analysis as there is no significant difference between them.

Table (3): Effect of Tramadol (40 mg/kg/day) Administration on Gonadal Activity of Male Rats.

\begin{tabular}{|c|c|c|c|c|c|}
\hline \multirow{2}{*}{$\underbrace{\text { Conditions }}_{\text {Parameters }}$} & \multirow{2}{*}{$\begin{array}{l}\text { Control } \\
\text { X+S.E. }\end{array}$} & \multicolumn{3}{|c|}{ Treatment (1 month) } & \multirow{2}{*}{$\begin{array}{c}\text { Recovery } \\
10 \text { days } \\
\text { X+S.E. }\end{array}$} \\
\hline & & $\begin{array}{l}10 \text { days } \\
X+\text { S.E. }\end{array}$ & $\begin{array}{l}20 \text { days } \\
X+\text { S.E. }\end{array}$ & $\begin{array}{l}30 \text { days } \\
\text { X+S.E. }\end{array}$ & \\
\hline $\mathrm{LH}(\mathrm{mlU} / \mathrm{ml})$ & $2 . \overline{5}+0.15$ & $2.1+0.11$ & $2.0+0.1$ & $1.4+0.1^{*}$ & $1.9+0.14$ \\
\hline $\mathrm{FSH}(\mathrm{mlU} / \mathrm{ml})$ & $2.0 \pm 0.11$ & $2.0 \pm 0.1$ & $1.9 \pm 0.1$ & $1.0 \pm 0.1^{*}$ & $1.65+0.12$ \\
\hline Tes.(ng/ml) & $4.0 \pm 0.4$ & $3.7 \pm 0.2$ & $2.6 \pm 0.1^{*}$ & $2.2 \pm 0.1 * *$ & $3.0 \pm 0.1^{*}$ \\
\hline $\mathrm{E}_{2}(\mathrm{pg} / \mathrm{ml})$ & $44.2+1.1$ & $46.5+1.2$ & $51.3 \pm 1.0 *$ & $61.5+1.2 * *$ & $52 . \overline{4}+1.1 *$ \\
\hline PRL(ng/ml) & $6.6+1.0$ & $8.2+0.9$ & $10.0+0.1 *$ & $12.9+0.11 *$ & $9.0+0.2$ \\
\hline Cor.(ng/ml) & $198+2.0$ & $194+1.4$ & $190+1.3$ & $182+1.2 *$ & $189 . \overline{5}+1.4$ \\
\hline
\end{tabular}

Control= The average of the results of control groups were used in the statistical analysis as there is no significant difference between them. 
Table (4): Effect of Tramadol $(80 \mathrm{mg} / \mathrm{kg} / \mathrm{day})$ Administration on Gonadol Activity of Male Rats.

\begin{tabular}{|c|c|c|c|c|c|}
\hline Conditions & Control & \multicolumn{3}{|c|}{ Treatment (1 month) } & Recovery \\
\hline Parameters & X+S.E. & $\begin{array}{l}10 \text { days } \\
\text { X+S.E. }\end{array}$ & $\begin{array}{l}20 \text { days } \\
\text { X+S.E. }\end{array}$ & $\begin{array}{l}30 \text { days } \\
\text { X+S.E. }\end{array}$ & $\begin{array}{l}10 \text { days } \\
\text { X+S.E. }\end{array}$ \\
\hline $\mathrm{LH}(\mathrm{mlU} / \mathrm{ml})$ & $2 . \overline{25}+0.15$ & $2.0 \pm 0.11$ & $1.3 \pm 0.6^{*}$ & $0.92+0.1 * *$ & $1 . \overline{ \pm} \pm 0.1^{*}$ \\
\hline FSH $(\mathrm{mlU} / \mathrm{ml})$ & $2.0 \pm 0.11$ & $1.9 \pm 0.1$ & $1.2 \pm 0.01 *$ & $0.82 \pm 0.01 * *$ & $1.2 \pm 0.1^{*}$ \\
\hline Tes.(ng/ml) & $4.0 \pm 0.4$ & $3.5 \pm 0.1$ & $2.2 \pm 0.1 * *$ & $1.4 \pm 0.1 * *$ & $2.6 \pm 0.11 *$ \\
\hline $\mathrm{E}_{2}(\mathrm{pg} / \mathrm{ml})$ & $44.2 \pm 1.1$ & $48.5 \pm 1.2$ & $62.3 \pm 1.0 * *$ & $73.5 \pm 1.6 * *$ & $55.0 \pm 2.0 *$ \\
\hline PRL(ng/ml) & $6.6 \pm 1.0$ & $8.9 \pm 1.2$ & $12.6+1.0 * *$ & $15.3 \pm 1.1 * *$ & $11.7 \pm 0.9^{*}$ \\
\hline Cor.(ng/ml) & $198 \pm 2.0$ & $192+1.6$ & $182 \pm 1.3 * *$ & $177 \pm 1.7 * *$ & $183.0 \pm 1.1^{*}$ \\
\hline
\end{tabular}

$*=$ Significant $(\mathrm{p}<0.05) \quad * *=$ Highly significant $(\mathrm{p}<0.01)$

Control $=$ The average of the results of control groups were used in the statistical analysis as there is no significant difference between them.

\section{Discussion}

Hepatic metabolism is a mechanism that converts drugs and other compounds into products that are more easily excreted and that usually have a lower pharmacological activity than the parent compound (Tolman, 1998). A metabolite may have higher activity and / or greater toxicity than the original drug. Metabolites of the drugs that are excreted via kidneys may also cause cellular damage leading to kidney dysfunction (Singhal et al., 1998).

The liver and kidney are responsible for tramadol metabolism and excretion. It may cause hepatotoxicity and nephrotoxicity during its metabolism (Wu et al., 2001; Janssen- Ortho Inc., 2005). Borzelleca et al. (1994) reported increased in ALT, AST and LDH activties in rats after long- term usage of morphine-like agent levo-alpha-acetylmethadol $\mathrm{HCl}$ (LAAM). Also, a significant increase in the levels of ALT, LDH and lipid peroxides was reported among chronic heroin users (Panchenko et al., 1999). Similarly, the present data was found significant increase in the levels of ALT, AST and LDH among rats received both doses of tramadol $(40 \mathrm{mg}$ and $80 \mathrm{mg} / \mathrm{Kg} \mathrm{b}$. wt.) with a pronounced effect caused by the large dose and the duration of drug administration.

On the other hand, current results indicated a slight increase in BUN and creatinine levels in rats received $40 \mathrm{mg} / \mathrm{Kg}$ tramadol after 30 days treatment but, $80 \mathrm{mg}$ $/ \mathrm{Kg}$ tramadol exerted moderate effects at 20 and 30 days treatment. These are in accordance with Atici et al. (2005) who reported an increase in BUN and creatinine levels in rats receiving morphine for a month and after long- term use of LAAM(Borzelleca et al.,1994).

Toxic effects of opioids at cellular level may be explained by lipid peroxidation. Biological membranes contain large amount of poly-unsaturated fatty acids, which are particularly susceptible to peroxidative attacks by oxidants resulting in lipid peroxidation. Therefore, lipid peroxidation has been used as an indirect marker of oxidant- induced cell injury (Lurie et al., 1995). A significant increase in lipid peroxides was reported in rats receiving an acute dose of cocaine (Masini et al., 1997). Similarly, lipid peroxides were found significantly increased among heroin users (Panchenko et al., 1999). These findings are in agreement with the present results which showed significant increase in serum MDA levels in both tramadol groups compared to control group, indicating an increase in lipid peroxidation.

The current data also revealed reduced levels of glucose, total cholesterol and triglycerides in both tramadol groups after 20 and 30 days treatment with more pronounced effect of large dose. These data 
supported by a recent study of Cheng et al. (2001) which showed that tramadol can decrease glycemia in diabetic rats, via the activation of opioid $\mu$-receptors, suggesting a mechanism possibly related to those of dextro-propoxyphene. Moreover, tramadol acts as serotonin reuptake inhibitor, and hypoglycemia has been described with some serotonin anti-depressants, sertraline (Peyrière et al., 2004). The hypoglycemic effect of Tramacet (tramadol containing product) has been also reported as a metabolic disorder that occurred as an incidence of less than $1 \%$ in clinical trails ( Janssen-Ortho Inc., 2005)

The reduction of total cholesterol and triglycerides levels in the present study received evidence from El- Gaafarawi (1990) who observed signifi-cant reduction in plasma total cholesterol and triglycerides levels after adminis-tration of opioid and non-opioid analgesics in rats. Also, Budzynski et al. (2000) reported reduction of serum total cholesterol and triglycerides levels in naltraxone (mu- antagonist) treated patients. In another study using some antiepileptics, Daoud et al. (2004) showed similar reduction in serum total cholesterol and triglycerides in addition to glucose levels.

The reduction of serum total cholesterol in the current study supported the reduction of testosterone levels in the same study where, $45 \%$ of cholesterol substrate for testosterone and sperm production was derived from plasma (Connor et al., 1997).

Sexual dysfunction as a consequence of drug therapy has been reported with a range of drugs. About 15\% of the 200 most commonly prescribed drugs can have adverse effects on male reproduction such as sedatives, tranquilizers, hypnotics, narcotics and cannabis (Chowdhury, 1987), antihypertensives, antipsychotics and antidepressants (Maclean and Lee, 1999). Mckim (2003) stated that opiate use is known to decrease the levels of sex hormones in both sexes and this lowered hormonal level is thought to be responsible for the diminished fertility of both male and female opiate users.

In the present study, gonadal examinations revealed that administration of tramadol $80 \mathrm{mg} / \mathrm{Kg} \mathrm{b}$. wt. for a month influenced sex hormones activity of male rats at 20 and 30 days of treatment compared to control group while, $40 \mathrm{mg} /$ $\mathrm{Kg}$ b. wt. tramadol influenced this activity to a lesser extent compared to $80 \mathrm{mg}$ tramadol group and control one.

Previous studies concerned with gonadal activity during drug therapy have been supported the present results. Chowdhury (1987) reported decreased levels of serum LH and testosterone with increased PRL secretion after morphine and methadone administration. Christensen et al. (1989) reported reduction of cortisol levels after 3 and 5 weeks treatment with antidepressants and increased PRL after sertraline adminis-tration (Broadbear et al. 2004). Also, Hezog et al. (2004) reported reduced testosterone and elevated $\mathrm{E}_{2}$ levels while Daoud et al. (2004) reported significant reduction in serum testosterone and FSH levels in antiepileptic treated patients and in rats respectively. ElGaafarawi et al.(2005) have been observed in an independent investigation, the reduction of serum levels of $\mathrm{LH}, \mathrm{FSH}$, testosterone and the induction of PRL secretion after paroxetine treatment.

On the other hand, the results of 10 days recovery period indicated that most of the measured parameters of $40 \mathrm{mg}$ tramadol group tended to be some what higher than the control group, whereas, $80 \mathrm{mg}$ tramadol group remained significantly different compared to control one. This may indicate that tramadol toxic effects induced by therapeutic doses are persisted after drug cessation, and the time of recovery is dependent on the concentration of administered dose.

\section{Conclusian}

Tramadol exerts its toxic effect via two distinct and synergistic mechanisms of actions. This may reflect the greater frequency of decreasing hepatic, renal and sexual functions. Physicians should be aware of aforementioned adverse effects and the glycemic disturbances related to tramadol.Dose selection should be cautious. 


\section{References}

1. American Association of Poison Control Centers (2002): Tramadol (Ultram), AAPCC Annual Report.

2. Albro P.W., J.T. Corbett and J.I. Schroder (1986): Application of the thiobarbituric assay to measurement of lipid peroxidation products in micros-omes.J. Biochem. Biophys. Methods, 13:185.

3. Atici S., I. Cinel, L. Cinel, N. Doruk, G. Eskandari and V. Oral (2005): Liver and kidney toxicity in chronic use of opioids: An experimental long term treatment model, J. Biosci. 30 (2): 245-252.

4. Borzelleca J.F., J.L. Egle, L.S. Harries, D.N. Johnson, J.B. Terrill and J.A. Belleville: (1994): Toxicological evaluation of $m \mu$-agonists. Part 1: Assessment of toxicity following 30 days of repeated oral dosing of male and female rats with levoalpha- acetylmethadol HCL (LAAM), J. Appl. Toxicol, 14: 435-446.

5. Broadbear J.H., L.C. Hutton, I.J. Clarke and B.J. Canny (2004): Sex differences in the pituitaryadrenal response following acute antidepressant treatm-ent in sheep. Psychopharmacology (Berl), 171 (4): 450457.

6. Budzynski J.,J. Rybakowski,M. Swiatkowski, L. Torlinski, M. Klopocka, W. Kosmowski and M. Ziolkowski (2000): Naltrexone exerts a favourable effect on plasma lipids in abstinent patients with alcohol dependence. Alcohol and Alcoholism, 35(1): 91-97.

7. Cheng J.T., I.M. Lui, T. Chi, T.F. Tzeng, F.H. Lu and CH.J. Chang (2001): Plasma glucose-lowering effect of tramadol in streptozotocin-induced diabetic rats. Diabetes 50: 2815-2821.

8. Chowdhury A.R.(1987): Effect of pharmacological agents on male reproduction. Adv Contracept Deliv. syst. 3 (4): 347-52.

9. Christensen P., A. Lolk, L.F. Gram and P. Kragh-Sorensen et al. (1989): Cortisol and treatment of depression: predictive value of spontaneous and suppres cortisol levels and cause of spontaneous plasma cortisol. 97 (4): 471-475.

10. Connor W.E., D.S. Lin and M. Neuringer (1997): Biochemical markers for puberty in the monkey testis: Desmosterol and Docosahex a enoic acid. The journal of Clinical Endocinology and Metabolism. vol. 82 (6): 1911-1916.
11. Cossman M. and C. Kohnen (1995): General tolerability and adverse event profile of tramadol hydrochloride. Revisions of Contemporary Pharmacotherapy, 6: 513-531.

12. Daoud A.S., H. Bataineh, S. Otoom and E. Abdul-Zahra (2004): The effect of Vigabatrin, Lamotrigine and Gabapentin on the fertility, weights, sex harmones and biochemical profiles of male rats. 25 (3):178-83.

13. Dayer P., J. Desmeules and L. Collart (1997): Pharmacology of tramadol. Drugs, 53 Suppl 2:18-24.

14. Drugs and Therapy Bulletin (2002): Ultracet, Vol.16 (5): 3, Shands at the University of Florida, pp.1-4.

15. El- Gaafarawi I.I.(1990): Biochemical effects of some analgesics. Ph. D.of biochemistry, Faculty of Science, Ain Shams University,Ciro, Egypt.

16. El-Gaafarawi I.I., M. Hassan, Gh. Fouad and F. El-Komey (2005): Toxic effects of paroxetine on sexual and reproductive fuctions of rats. The Egyptian Journal of Hospital Medicine. Vol. 21:16-32.

17. Flegg H.M.(1973): Determination of serum cholesterol by an enzymatic methods. Ann. Clin. Biochem., 10:79.

18. Food and Drug Administration Committee, FDA(1998): FDC Reports (pink sheets) prescription pharmaceuticals and bio-technology. 60:4-5.

19. Fossati P.and L. Prencipe (1982): Serum triglycerides determined colorimetrically with an enzyme that produces hydrogen peroxide. Clinical Chemistry, 28:2077.

20. Fossati P., L. Prencipe and G. Berti (1983): Enzymatic creatinine assay, a new colorimetric method based in hydrogen peroxide measurement. Clinical Chemistry, 29:1494.

21. Gardner J.S., D. Blough, C.R. Drinkard et.al.(2000): Tramadol and seizures: a surveillance study in a managed care population. Pharmacotherapy. 20:1423-1431.

22. Gasse C., L. Derby, C. Vasilakis-Scaramozza and H. Jick (2000): Incidence of first- time idiopathic seizures in users of tramadol. Pharmacotherapy. 20: 629-634.

23. Gibson T.P.(1996): Pharmacokinetics, efficacy, and safety of analgesia with a focus on tramadol HCl. Am.J. Med. 101(1A): 47S-53S.

24. Gillman P.K.(2005): Monoamine oxidase inhibitors, opioid analgesics and serotonin toxicity. British J.Anaesth.95(4): 434-441. 
25. --Grond S.and A. Sablotzki (2004): Clinical pharmacology of treatment. Clin. Pharmacokinet. 43(13): 879-923.

26. Herzog A.G., F.W. Drislane, D.L. Schomer, P. B. Pennell et al. (2004): Differntial effects of antiepileptic drugs on sexual function and reproductive hormones in men with epilepsy: interim analysis of a comparison between lamot-rigine and enzyme inducing antiepileptic drugs. Epilepsia, 45(7): 764-768.

27. Houmes M., M.A. Voets, A. Verkaaik, W. Erdmann and B. Lachmann(1992): Efficacy and safety of treatment of tramadol versus morphine for moderate and severe postoperative pain with special regard to respiratory depression. Anesth. Analg. 74: 510-514.

28. Janssen-Ortho Inc.(2005): Tramacet, a product monograph., pp.1-36, www. janssen- ortho.com.

29. Jick H., L.E. Derby, C. Vasilakis and D. File (1998): The risk of seizures associated with tramadol. Pharmacotherapy, 18(3): 607-611.

30. Lewis K.S. and N.H. Han (1997): Tramadol, a new centrally acting analgesic. Am.J.Health Syst.Pharm.,54 (6): 643-652.

31. Lurie E., A. Soloviova, T. Alyabieva, A. Kaplun, L. Panchenko and V. Shvets (1995): Effect of novel aromatic derivative of GABA on lipid peroxidation in chronically morphinized rats. Biochem. Biol. Int., 36: 13-19.

32. Maclean F.M. and A. Lee (1999): Drug induced sexual dysfunction and infertility. The Pharmaceutical Journal, 262(7047): 780-784.

33. Mattiessen T., T. Wohrmann, T.P. Coogan and H. Uragg (1998): The experimental toxicology of tramadol, an overview. Toxicol. Lett., 95:63-71.

34. Masini A., D. Gallesi, F. Giovannini and D. Ceccarelli(1997): Membrane potential of hepatic mitochondria after acute cocaine administration in rats- the role of mitochondria reduced glutathione. Hepatology, 25:385-390.

35. Mckim W.A.(2003): Drug and behavior, an introduction to behavioral pharmacology. Prentice Hall, New Jersey, $5^{\text {th }}$ ed., p.243.

36. Orsonneau J., C. Massoubre and $M$. Cabanes (1992): Simple and sensitive determination of urea in serum and urine. Clinical Chemistry, 38:619.

37. Paget G.E. and J.M. Barnes (1964): Evaluation of drug activities and pharmacometrics. Laurence D.R. and A. L. Bacharach, Eds., Academic Press, London, Vol.1: 135-166.

38. Panchenko L. F., S.V. Pirozhkov, A.V. Nadezhdin, V.I. Baronets and N.N. Usamanova (1999): Lipid peroxidation, peroxyl radical-scavenging system of plasma and liver and heart pathology in adolescence heroin users. Vopr.Med. Khim. 45:501-506.

39. Pang W.W., H.S. Wu and C.C. Tung (2003): Tramadol $2.5 \mathrm{mg}$ (middle dot) $\mathrm{kg}^{-1}$ appears to be the optimal intraoperative loading dose before patient-controlled analgesia (French Article). Can. J. Anesth; 50 (1): 48-51.

40. Peyrière H., M. Villiet, V. Alibert, M. Creus et al. (2004): Hypoglycemia related to tramadol therapy. Analysis of cases reported in the French Pharmacology 18: 215-268.

41. Raffa R.B. (1996): A novel approach to the pharmacology of analgesic. Am. J. Med., 101 (1A): 40S-46S.

42. Raffa R.B., E. Friderichs, W. Reimann, R.P. Shank, E.E. Codd and J.I. Vaught (1992): Opioid and non-opioid components independently contribute to the mechanism of action of tramadol, an "atypical" opioid analgesic. J. Pharmacol. Exp. Ther., 260 (1): 275-285.

43. Scandinavian Society for Clinical Chemistry and Clinical Physiology (1974): Recommended methods for four enzymes in blood. Scand. J. Clin. Lab. Invest., 33:291-306.

44. Singhal P.C., P. Sharma, V. Sanwal, N. Prassad, A. Kapasi, R. Ranjan, N. Franki, K. Reddy and N. Gibbons (1998): Morphine modulates proliferation of kidney fibroblasts, Kidney Int.,53: 350-357.

45. Spiller H., S. Gorman, D. Villalobos, B. Benson et al. (1997): Prospective multicenter evaluation of tramadol exposure. Clinical Toxicology. 35: 361-364.

46. Tao Q., D.J. Stone, M.R. Borenstein, E.E. Codd and T.P. Coogan (2002): Differential tramadol and O-desmethy metabolite levels in brain vs plasma of mice and rats administered tramadol hydrochloride orally.J.Clin. Pharm. Therap. 27: 99106.

47. Tarkkila P., M. Tuominen and L. Lindgren (1998): Comparison of respiratory effects of tramadol and pethidine. Eur J. Anaesthesiol., 15 (1): 64-8.

48. Thomas L.(1998): Alanine aminotransferase (ALT), aspartate aminotrasferase 
(AST), in Thomas, L. editor. Clinical Laboratory Diagnostics. Frankfurt: TH-Books Verlagsgesellschaft, $1^{\text {st }}$ ed., pp.55-56.

49. Tobias J.D. (1997): Seizure after overdose of tramadol. South Med.J., 90 (8): 826-827.

50. Tolman K.G. (1998): Hepatotoxicity of non-narcotic analgesics. Am. J. M., 105(1B): 13S-19S.

51. Trinder P.(1969): Determination of glucose in blood using glucose oxidase with alternative oxygen acceptor. Ann. Clin. Bioch.,6:24.
52. Wilder-Smith C.H., L. Hill, W. Osler and S.Okeefe (1999): Effect of tramadol and morphine on pain and gastrointestinal motor fuction in patients with chronic pancreatitis. Digestive Diseases and Sciences, 44:1107-1116.

53. Wu W.N., L.A. Mcknown, A. D. Gauthier, W.J. Jones and R.B. Raffa (2001): Metabolism of analgesic, tramadol hydrochloride, in rat and dog. Xenobiotica, 31: 423-441. 


\title{
السمية الكيميائية الحيوية الناتجة عن تاثير عقار الترامادول في ذكور الجرذان
}

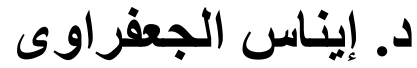 \\ المركز القومى للبحوث الاجتماعية و الجنائية
}

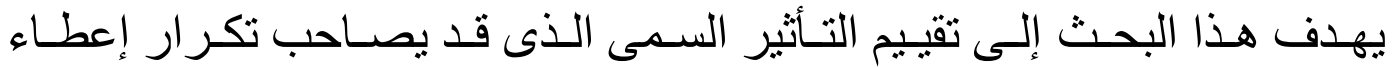

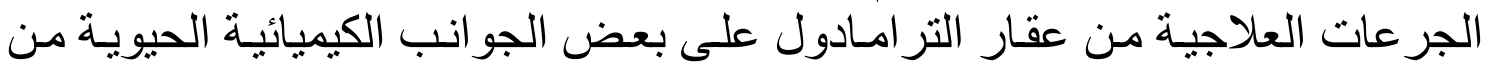

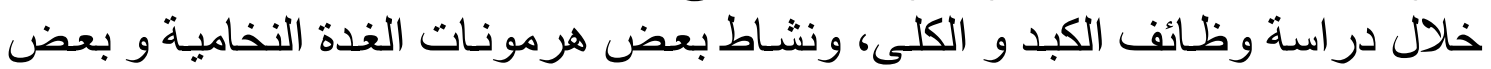
هرمونات التناسل، و كذللك بعض معدلات التمثيل الغذائى (الأيض) في ذكور الجرذات الغدان البيضاء.

و قد استخدم في ذلك ثلاث مجمو عات من ذكور الجرذان، أعطيت الأولى منها

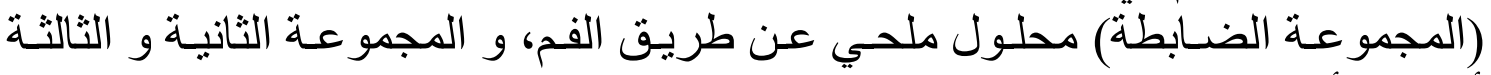

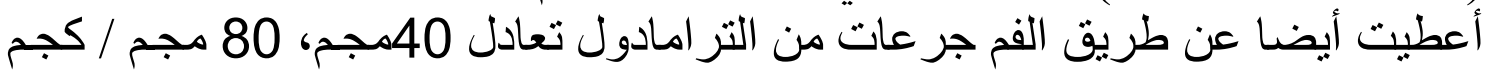

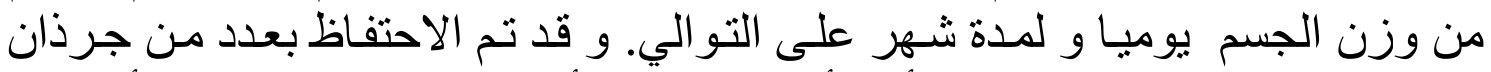

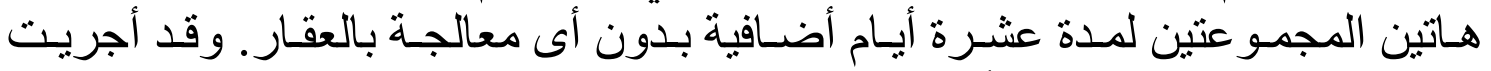

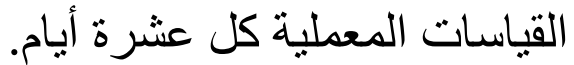

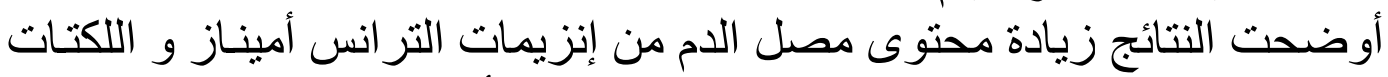

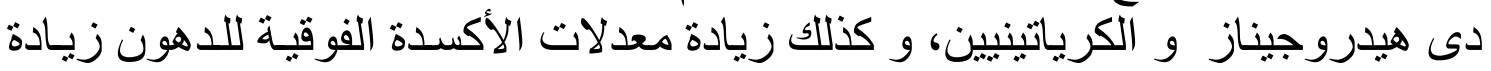
ذو دلالة معنوية لكلتا الجر عتين.

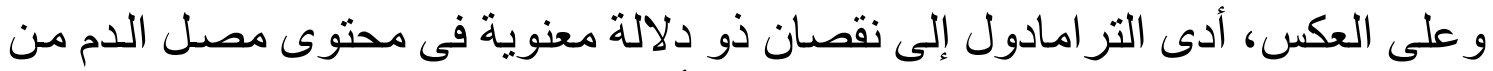

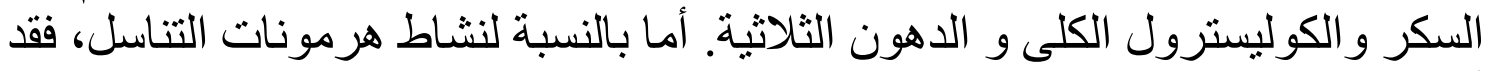

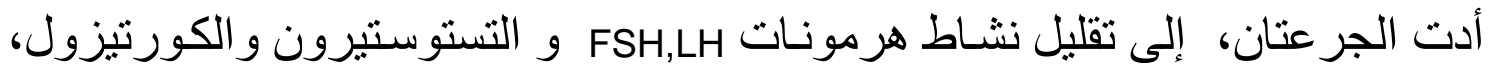

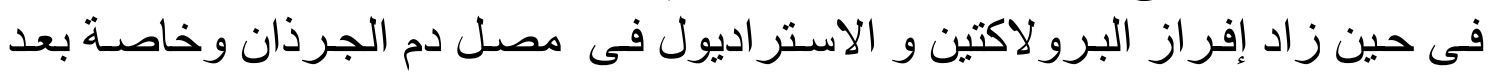

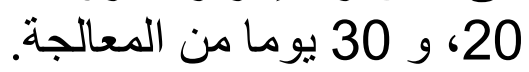

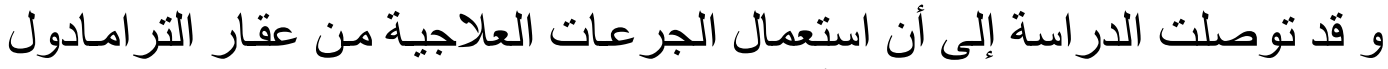

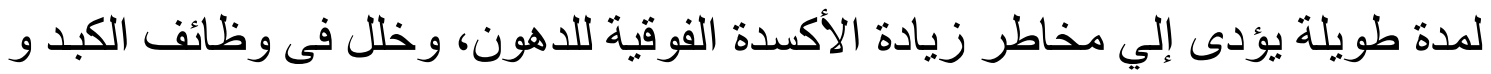

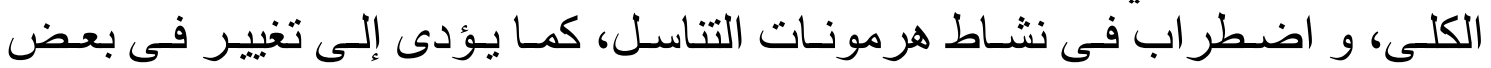

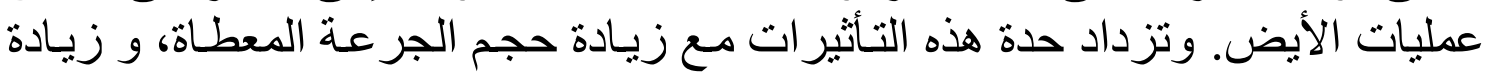

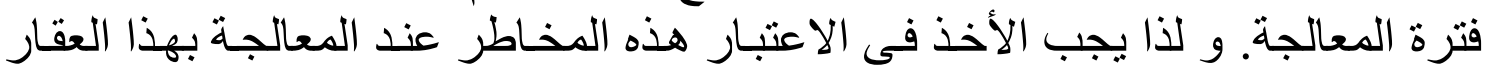

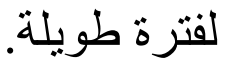

